\title{
Groundwater Vulnerability Assessment and Validation for a Fast Growing City in Africa: A Case Study of Lagos, Nigeria
}

\section{Oluwapelumi O. Ojuri, Olufunmilola T. Bankole}

Federal University of Technology, Akure, Nigeria.

Email: ojurip@yahoo.com

Received February $6^{\text {th }}, 2013$; revised March $8^{\text {th }}, 2013$; accepted April $5^{\text {th }}, 2013$

Copyright (C) 2013 Oluwapelumi O. Ojuri, Olufunmilola T. Bankole. This is an open access article distributed under the Creative Commons Attribution License, which permits unrestricted use, distribution, and reproduction in any medium, provided the original work is properly cited.

\begin{abstract}
Lagos is the world's sixth largest city, the most populous city in Africa and the most populous city in Nigeria. A total of eighteen groundwater exploitation borehole logs together with hydrogeological and geotechnical data were used for the study. The eighteen available borehole logs were categorized into seven areas spanning the shoreline to inland boundary of Lagos State. The study area has a high net recharge of $1838 \mathrm{~mm} / \mathrm{yr}$ and the aquifer media is sand. The intrinsic vulnerability map show areas of highest potential for groundwater pollution based on hydro-geological condition and human impacts. Seven major hydro-geological factors incorporated into DRASTIC model and the geographic information system (GIS) were used to create a groundwater vulnerability map by overlaying the available hydro-geological data. The output map shows that the southeast of the aquifer is under very high vulnerability while central parts of aquifer have high vulnerability. Other parts (north, northwest and south) of the study area have moderate vulnerability to pollution. For testing of the vulnerability assessment, groundwater quality data were collated from literature for the different vulnerability zones of the study area. The chemical analysis results show that both the southeast and northwest west parts of study area aquifer (very high and moderate vulnerability zones) have higher nitrate concentration relative to the rest of aquifer, that are located in high vulnerability zone. The validation of the DRASTIC models was accomplished through pair wise comparison of DRASTIC vulnerability maps (using Pearson's $r$ correlation coefficient) with a total of 14 layers representing original DRASTIC input data, Land cover (LC) features, and groundwater TDS, $\mathrm{Cl}^{-}$and $\mathrm{NO}_{3}$ data. Results from the correlation analysis indicate a significant association between high groundwater $\mathrm{TDS}, \mathrm{NO}_{3}$ concentrations and distances from certain LC types.
\end{abstract}

Keywords: Intrinsic Vulnerability; Hydrological Fluxes; Groundwater Protection; Pollution Source Proximity

\section{Introduction}

In developing countries in Africa, Asia and South America for an estimated 1300 million urban dwellers the main source of drinking water is groundwater. This groundwater may be contaminated by infiltrated wastewater, because very often a sewer system is not present and households dispose of their solid and liquid waste on-site [1]. For instance, in Africa around $80 \%$ of the population in the largest cities (in Asia: around 55\%) have on-site sanitation, such as septic tanks, pour-flush, VIP latrines or simple pits [2]. Lagos city (Figure 1), the commercial nerve center of Nigeria also has threats to its ground water from open waste dumps, petroleum product underground infrastructure, a massive un-engineered landfill site (Olusosun landfill) and large surface water bodies (Lagos lagoon and the Atlantic Ocean).

Groundwater vulnerability procedures can be classified into three categories: 1) overlay and index method;2) process based methods that apply deterministic models based on physical processes; and 3) statistical models. These methods are typically intended to provide a comparative evaluation of areas related to the potential for groundwater contamination [3]. The overlay and index methods result from the intersection of maps on a regional basis and the qualitative interpretation of the data by indexing the parameters and assigning appropriate weights. The maps have both physical and climatic attributes that are assigned numerical indices for each attribute. 


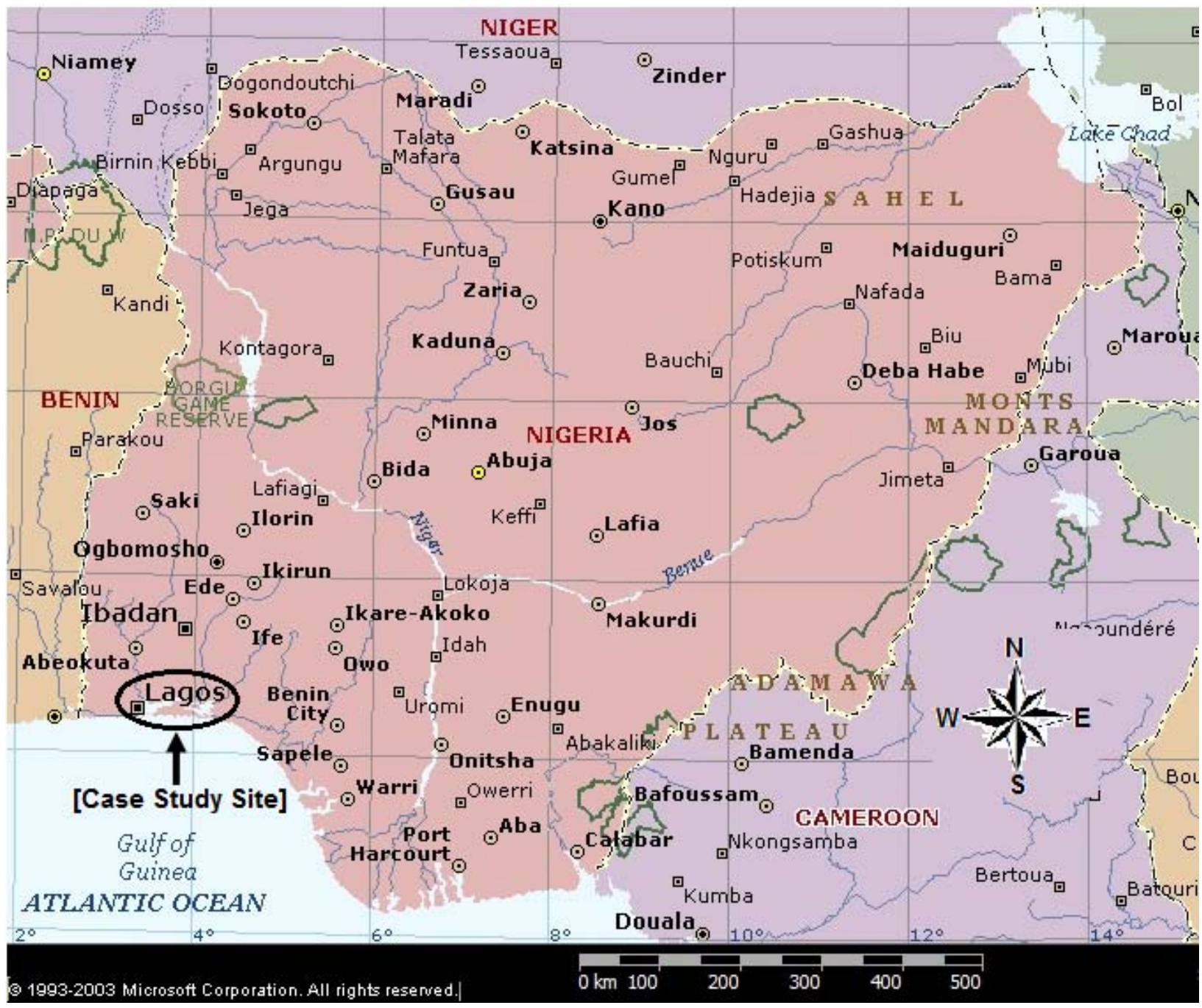

Figure 1. Map of Nigeria showing Lagos, the case study site.

The DRASTIC system [4], which falls under the index category, is the best known of these methods. It was developed in the United States with the support of the US. Environmental Protection Agency (EPA) and was designed to be a standardized system for evaluating the groundwater vulnerability for a variety of land areas. It was not intended to produce an absolute measure of vulnerability, but can be one of many criteria used in decision making. Parallel with the development of DRASTIC, the GOD method [5] was developed in Europe, which consists of three parameters: Groundwater occurrence, Overall aquifer class and Depth to water table. The Aquifer Vulnerability Index (AVI) method [6] developed in Canada, considers depth and hydraulic conductivity of each sedimentary layer above the ground-water level and the vertical hydraulic gradient. The UK vulnerability system [7] identifies three important components of groundwater vulnerability: soil type, the presence/absence of drift and the nature of the aquifer. All these methods can be carried out within a GIS-based framework where they have been mainly used to delineate the areas that are more vulnerable to pollution than others or to select the most favorable areas for sitting well fields and/or hazardous land use activities. The DRASTIC method has received much criticism due to lack of proper validation. For example, a positive correlation between the model results and field data was reported by $[8,9]$, while others have reported little correlation [10,11]. Despite these concerns DRASTIC has been applied worldwide with adaptations on the procedures to elaborate thematic maps and the use of different ratings criteria [12-15]. There are also some methodologies that integrate various elements of the index methods with other information, such as contaminant loading and land use/land cover (LULC) to estimate the expected risk to groundwater contamination on a regional scale [16-18]. Lagos in southwestern Nige- 
ria is a port city. It is the world's sixth largest city and the most populous city in Africa. The United Nations puts its population at over 18 million with a density of 5032 persons per $\mathrm{km}^{2}$, and it is projected to reach 20 million by 2010 and 24.6 million by year 2015 to rank as the third most populous megacity in the world $[19,20]$. It has the fastest-growing urban population in the world at 6 to 8 per cent annually, ten times faster than New York and Los Angeles. Lagos State is highly urbanised, capturing 37 to 41 percent of Nigeria's urban population. Lagos State only occupies 0.4 percent of the country's land area and gains extra 300,000 inhabitants every year on top of its natural growth rate. It is the economic nucleus of the country, reputed to account for about 57 percent of total value added in manufacturing and about 40 percent of the nation's most highly skilled manpower [21]. Metropolitan Lagos situated on the narrow lowland coastal stretch bordering the Atlantic Ocean and originally covered with mangrove swamps has experienced significant land cover changes due to past and present reclamation activities to secure more and more land for urban development. Land reclamation achieved through filling up of swamps and floodplains, and destruction of mangroves and wetlands have generally reduced the flood storage capacity of the urban land. Rapid and largely unplanned urban growth has resulted in land use changes and subsequent changes in the hydrological fluxes in the urban watershed thereby increasing flood hazard and risk in many parts of the metropolis and this can create unforeseen trends in the depth to groundwater table pattern for the different parts of Lagos [22]. This paper presents a method to assess groundwater vulnerability to pollution and risk mapping with limited data based on the integration of a GIS-based DRASTIC method with groundwater quality data and the proximity analysis of groundwater pollution aggravating land cover features for Lagos, $\mathrm{Ni}$ geria.

\section{Materials and Methods}

\subsection{Description of Study Area}

Situated in the south western corner of the country, Lagos state spans the Guinea coast of the Atlantic Ocean for over $180 \mathrm{~km}$, from the Republic of Benin on the west to its boundary with Ogun state in the east. It extends approximately from latitude $6^{\circ} 23^{\prime}$ North to $6^{\circ} 41^{\prime}$ North, and from longitude $2^{\circ} 42^{\prime}$ East to $3^{\circ} 42^{\prime}$ East. It has a total area of $3577 \mathrm{sq} . \mathrm{km}$, about $787 \mathrm{sq} . \mathrm{km}$ or $22 \%$ is water. Seven (7) local government areas that cut across the landscape of Lagos state from the shoreline to the inland boundary were used for this study based on available data. The Areas are as shown on the map of Lagos State below in Figure 2. They are;

- Area 1: Eti-Osa LGA (Victoria Island, Ikoyi and Lekki);

- Area 2: Apapa LGA (Apapa);

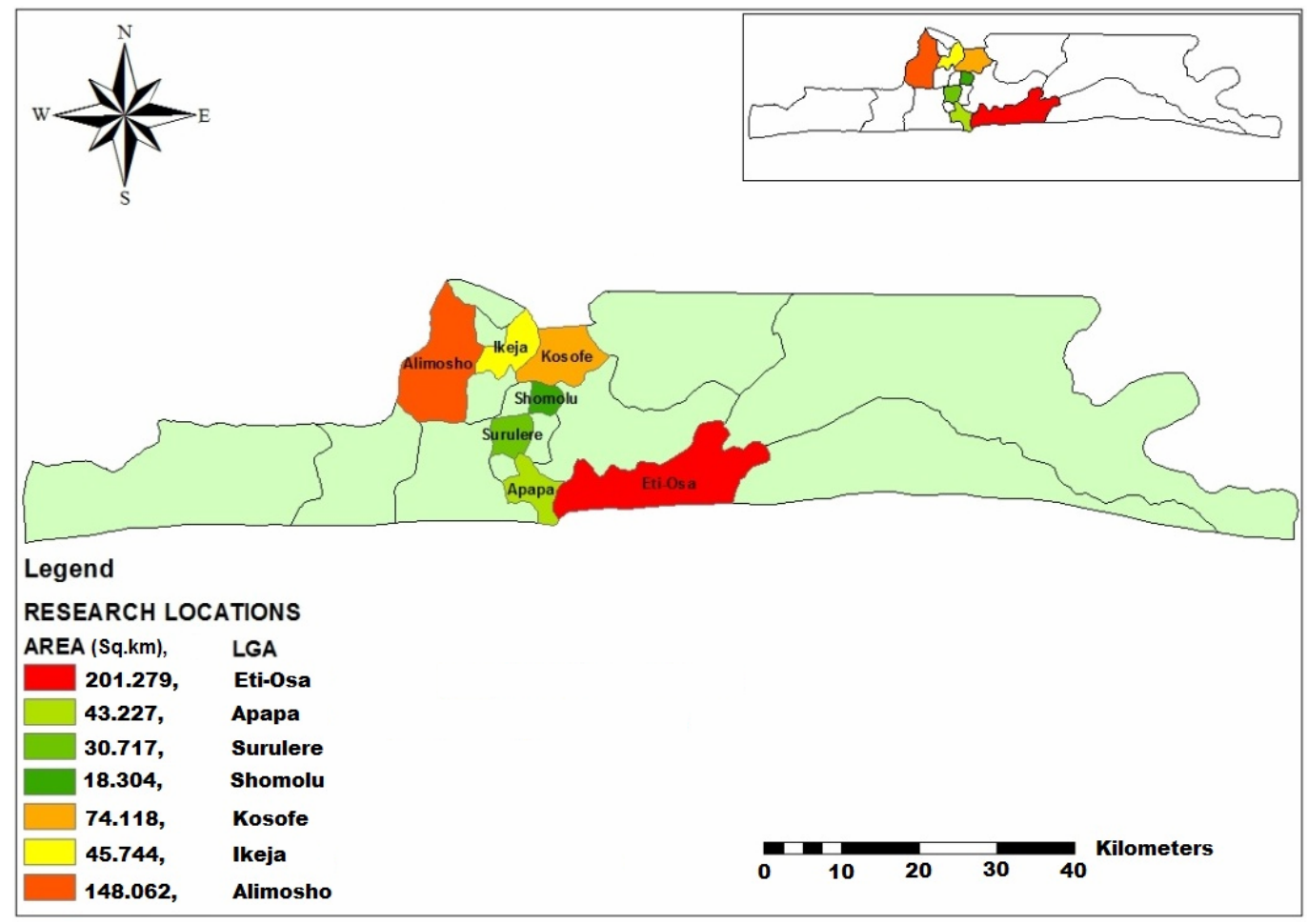

Figure 2. Map of Lagos State showing the study areas. 
- Area 3: Surulere LGA (Surulere and Cele);

- Area 4: Shomolu LGA (Gbagada);

- Area 5: Kosofe LGA (Isheri, Ogudu);

- Area 6: Ikeja LGA (Ogba);

- Area 7: Alimosho LGA (Ipaja, Gowon Estate).

\subsection{Collation and Analysis of Existing Groundwater Supply Borehole Exploitation Logs and Soil Survey Reports}

The data used for this project was retrieved from multiple sources. A total of eighteen borehole log were collected from Trevi Foundations Nigeria limited, T.A.E Engineering limited and the Lagos Water Corporation (LWC). The depth to water table, and soil type for the different layers were extracted from the borehole logs. Information on geology, topography and soil features of Lagos state was obtained from the reconnaissance soil survey of Nigeria [23]. Representative values of saturated hydraulic conductivity for the different areas were estimated based the soil textures in the borehole logs. The climatic data was obtained from [24]. All the data were stored, integrated, manipulated, analyzed, and visualized using ArcGIS version 9.3 software and its extensions, namely, 3D Analyst, Spatial Analyst, and Geostatistical Analyst [25].

\subsection{Vulnerability/GIS Studies}

The Point Count System Model (PCSM) [26] a parametric method for groundwater vulnerability assessment was used to assess the sensitivity of the groundwater system to human and natural impacts. The procedure begins with a selection of parameters judged to be representative for vulnerability assessment. A multiplier (importance weight) was assigned to each parameter to reflect the relationship among the parameters and their importance for vulnerability/impact assessment. Each of the selected parameters has a given range, which is subdivided into discrete hierarchical intervals. Each interval was assigned a value reflecting the relative degree of vulnerability, and the rating points were summed. The final numerical score was divided into segments (mapping) expressing a relative vulnerability degree. The Geographic Information System (GIS) ESRI, ArcGIS 9.3 was combined with the DRASTIC model a point count system model, to produce intrinsic vulnerability maps for the area of case study. DRASTIC is a groundwater quality model for evaluating the pollution potential of large areas using the hydrogeologic settings of the region. A hydrogeologic setting is defined as a mappable unit with common hydro-geologic characteristics. This model employs a numerical ranking system that assigns relative weights to various parameters that help in evaluation of relative groundwa- ter vulnerability to contamination. The hydrogeologic settings, which make up the acronym DRASTIC are: [D] Depth to water table: [R] Recharge (Net): [A] Aquifer Media: [S] Soil Media: [T] Topography (Slope): [I] Impact of Vadose Zone: [C] Conductivity (Hydraulic).

DRASTIC evaluates contamination potential based on the above seven hydrogeologic settings. Each factor is assigned a weight based on its relative significance in affecting the pollution potential. Each factor is further assigned a rating for different ranges of values. The typical ratings range from $1-10$ and weights are from 1 5. The summary is shown in Table $\mathbf{1 .}$

\subsection{Groundwater Quality Data and Estimation of Pollution Aggravating Land Cover Feature Proximity}

A total of 40 well water samples from ten different communities of Lagos metropolis (i.e. coastal area (16), intermediate area (8) and interland (16) were collected and analysed by [28]. The generated data were subjected to basic statistical analysis and the mean value for each area recorded. Groundwater quality data compiled from literature [28,29] for the seven study locations (local government areas) are summarized in Table 2. The examined parameters are; Temperature, $\mathrm{pH}$, electrical conductivity (EC), Total dissolved solids (TDS), Chloride ( $\mathrm{Cl}^{-}$), and Nitrate $\left(\mathrm{NO}_{3}^{-}\right)$.

The DRASTIC Index, a measure of contamination potential is computed by summation of the products of ratings and weights for each factor as follows: DRASTIC Index $=\mathrm{DrDw}+\mathrm{RrRw}+\mathrm{ArAw}+\mathrm{SrSw}+\mathrm{TrTw}+\mathrm{IrIw}+$ $\mathrm{CrCw}$ where

Dr $=$ Ratings to the depth to water table

Dw $=$ Weights assigned to the depth to water table

$\mathbf{R r}=$ Ratings for ranges of aquifer recharge

$\mathbf{R w}=$ Weights for the aquifer recharge

Ar $=$ Ratings assigned to aquifer media

$\mathbf{A w}=$ Weights assigned to aquifer media

$\mathbf{S r}=$ Ratings for the soil media

$\mathbf{S w}=$ Weights for soil media

$\mathbf{T r}=$ Ratings for topography (slope)

$\mathbf{T w}=$ Weights for topography

$\mathbf{I r}=$ Ratings assigned to vadose zone

$\mathbf{I w}=$ Weights assigned to vadose zone

$\mathbf{C r}=$ Ratings for rates of hydraulic conductivities

$\mathbf{C w}=$ Weights given to hydraulic conductivity

The higher the DRASTIC index is, the greater the relative contamination potential is. The DRASTIC index can be further divided into four categories: low, moderate, high, and very high.

Figure 3 shows the location of the Atlantic Ocean [AO], Lagos Lagoon [LL], and Olusosun Landfill [OL]), 
Table 1. DRASTIC rating system and weights [27].

\begin{tabular}{|c|c|c|c|}
\hline & Range & Rating & Weight \\
\hline \multirow{7}{*}{ [D] Depth to water table (Feet) } & $0-5$ & 10 & \\
\hline & $5-15$ & 9 & 5 \\
\hline & $15-30$ & 7 & \\
\hline & $30-50$ & 5 & \\
\hline & $50-75$ & 3 & \\
\hline & $75-100$ & 2 & \\
\hline & $100+$ & 1 & \\
\hline \multirow{5}{*}{ [R] Recharge (Net) (Inches) } & $0-2$ & 1 & \\
\hline & $2-4$ & 3 & 4 \\
\hline & $4-7$ & 6 & \\
\hline & $7-10$ & 8 & \\
\hline & $10+$ & 9 & \\
\hline \multirow{11}{*}{ [A] Aquifer Media } & Massive Shale 1 & 2 & \\
\hline & Metamorphic & 3 & \\
\hline & Igneous $2-5$ & 4 & 3 \\
\hline & Weathered Metamorphic/Igneous 3 - 5 & 5 & \\
\hline & Glacial Till 4 - 6 & 6 & \\
\hline & Bedded Sandstone, Limestone and Shale Sequesnces 5 - 9 & 6 & \\
\hline & Massive Sandstone 4 - 9 & 8 & \\
\hline & Massive Limestone 4 - 9 & 8 & \\
\hline & Sand and Gravel 4 - 9 & 9 & \\
\hline & Basalt 2 - 10 & 10 & \\
\hline & Karst Limestone 9 - 10 & & \\
\hline \multirow{12}{*}{ [S] Soil Media } & Thin or Absent & 10 & \\
\hline & Gravel & 10 & \\
\hline & Sand & 9 & \\
\hline & Peat & 8 & \\
\hline & Shrinking and/or Aggregated Clay & 7 & 2 \\
\hline & Sandy Loam & 6 & \\
\hline & Loam & 5 & \\
\hline & Silty Loam & 4 & \\
\hline & Clay Loam & 3 & \\
\hline & Muck & 2 & \\
\hline & Nonshrinking and Nonaggregated & & \\
\hline & Clay & 1 & \\
\hline \multirow{5}{*}{ [T] Topography (Slope) } & $0-2$ & 10 & \\
\hline & $2-6$ & 9 & 1 \\
\hline & $6-12$ & 531 & \\
\hline & $12-18$ & & \\
\hline & $18+$ & & \\
\hline \multirow{11}{*}{ [I] Impact of Vadose Zone } & Confining Layer 1 & 1 & \\
\hline & Silt/Clay 2 - 6 & 3 & \\
\hline & Shale $2-6$ & 3 & 5 \\
\hline & Limestone 2 - 5 Sandstone 2 - 7 & 3 & \\
\hline & Bedded Limestone, & 6 & \\
\hline & Sandstone, Shale 4 - 8 & & \\
\hline & Sand and Gravel with significant Silt and Clay 4 - 8 & 6 & \\
\hline & Sand and Gravel 4 - 8 Basalt 2 - 10 & 6 & \\
\hline & Karst Limestone 8 - 10 & 8 & \\
\hline & & 9 & \\
\hline & & 10 & \\
\hline \multirow{6}{*}{ [C] Conductivity (Hydraulic) (GPD/FT^2) } & $1-100$ & 1 & \\
\hline & $100-300$ & 2 & \\
\hline & $300-700$ & 4 & 3 \\
\hline & $700-1000$ & 6 & \\
\hline & $1000-2000$ & 8 & \\
\hline & $2000+$ & 10 & \\
\hline
\end{tabular}


Table 2. Physical and chemical analysis of groundwater water samples from Lagos metropolis [28,29].

\begin{tabular}{cccccccc}
\hline Location & Temp. $\left({ }^{\circ} \mathbf{C}\right)$ & $\mathbf{p H}$ & $\mathbf{E C}(\boldsymbol{\mu S} / \mathbf{c m})$ & TDS $(\mathbf{m g} / \mathbf{l})$ & $\mathbf{C l}^{-}(\mathbf{m g} / \mathbf{l})$ & $\mathbf{N O}_{3}^{-}(\mathbf{m g} / \mathbf{l})$ \\
\hline Eti-Osa [ETS] & 29.70 & 6.40 & 817.50 & 415.00 & 393.10 & 5.19 \\
Apapa [APP] & 29.80 & 6.20 & 671.00 & 311.50 & 254.30 & 2.19 \\
Surulere [SLR] & 30.40 & 6.10 & 183.00 & 473.10 & 162.20 & 0.37 \\
Shomolu [SHL] & 26.60 & 6.40 & 63.20 & 29.70 & 15.84 & 30.80 & 1.20 \\
Kosofe [KSF] & 29.50 & 6.50 & 198.80 & 95.10 & 238.50 & 23.60 & 1.12 \\
Ikeja [IKJ] & 29.10 & 6.40 & 444.50 & 211.00 & 53.68 & 1.50 \\
Alimosho [ALM] & 26.80 & 6.00 & 437.00 & &
\end{tabular}

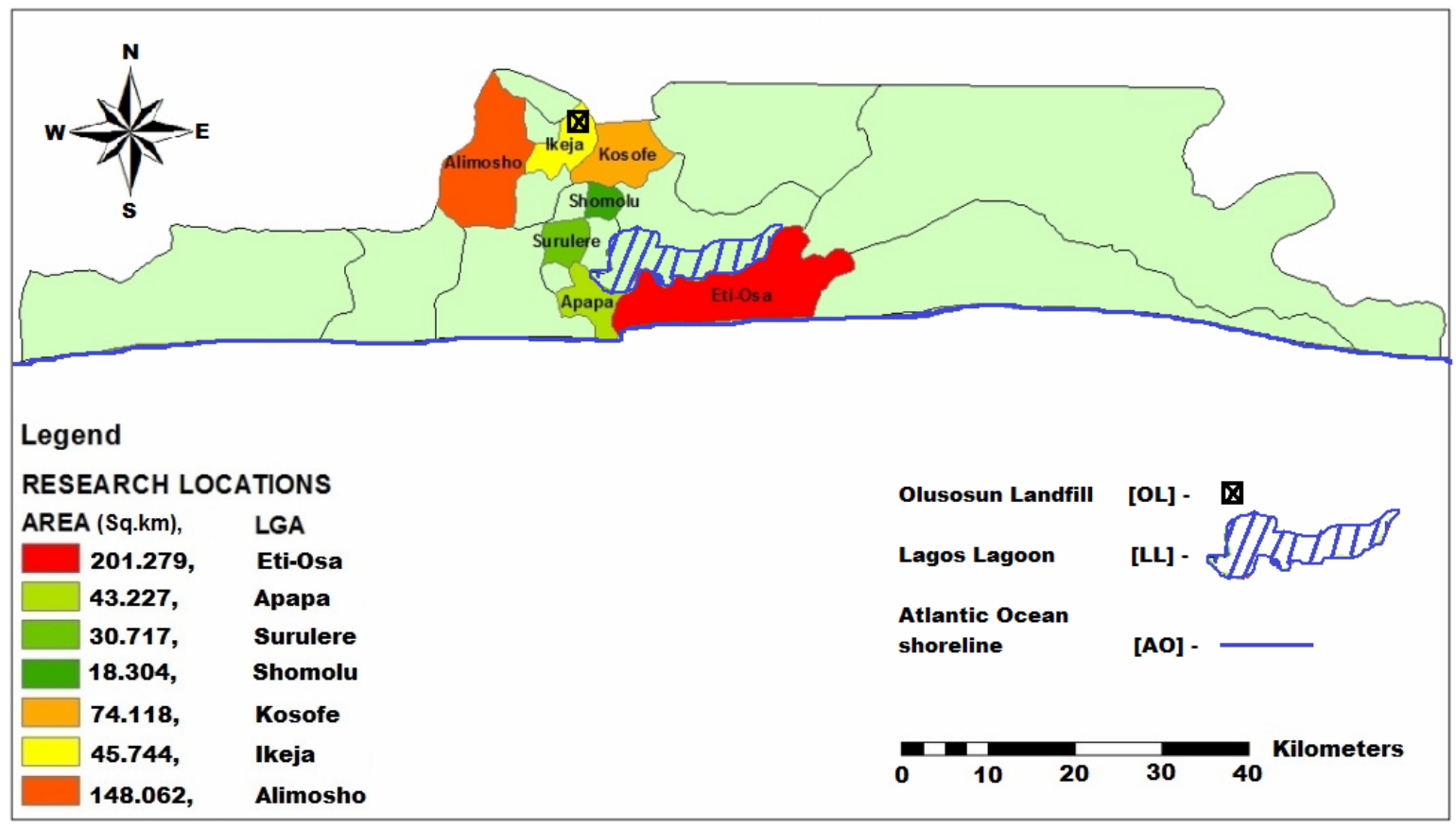

Figure 3. Location of groundwater pollution aggravating land cover features for Lagos, Nigeria.

these are considered as groundwater pollution aggravating land cover features for Lagos metropolis. The Olusosun landfill occupies approximately 42 ha of land in Oregun, Ikeja Local Government Area, Lagos State. The site had been used in the past as a burrow pit where sand was mined for road construction. Initial excavation depth of 7 to $12 \mathrm{~m}$ existed before tipping of waste commenced. The unlined landfill (This is usually the case in developing countries) accepts, officially, non-hazardous solid wastes of domestic, market, commercial, industrial and institutional origins but in practice all types of wastes are co-disposed [30] (Longe and Enekwechi, 2007). The Lagos lagoon and the Atlantic Ocean are large surface bodies distraught with anthropogenic pollution of diverse nature in Lagos metropolis. The distances from each of these features to the center of each study zone is approximated in Table 3.

\section{Results and Discussions}

\subsection{Vulnerability/GIS Studies Results}

The computation of the DRASTIC indices for the seven delineated zones within the study area can be seen in Table 4 to Table 10. Figure 4 shows the plot of the resulting intrinsic vulnerability map, using the ArcGIS 9.3. The results show that Area 1 (Eti-Osa LGA) (shades of red) consisting of Victoria Island, Ikoyi and Lekki suburbs, south east of the study are has the highest vulnerability index (208), and therefore has the greatest contamination potential. Area 7 (Alimosho) (shades of green), 
Table 3. Approximate distances from groundwater pollution aggravating land cover features for Lagos metropolis.

\begin{tabular}{cccc}
\hline Location & $\begin{array}{c}\text { Distance from Atlantic Ocean } \\
\text { [DAO] } \mathbf{( k m )}\end{array}$ & $\begin{array}{c}\text { Distance from Lagos Lagoon } \\
\text { [DLL] } \mathbf{( k m )}\end{array}$ & $\begin{array}{c}\text { Distance from Olusosun Landfill } \\
\text { [DOL] }(\mathbf{k m})\end{array}$ \\
\hline Eti-Osa [ETS] & 2.5 & 2.5 & 22.0 \\
Apapa [APP] & 2.5 & 2.5 & 20.0 \\
Surulere [SLR] & 8.0 & 4.0 & 16.0 \\
Shomolu [SHL] & 14.0 & 3.0 & 12.0 \\
Kosofe [KSF] & 18.0 & 13.0 & 3.0 \\
Ikeja [IKJ] & 22.0 & 17.0 & 1.5 \\
Alimosho [ALM] & 20.0 & 15.0 & 6.0 \\
\hline
\end{tabular}

(Atlantic Ocean [AO], Lagos Lagoon [LL], and Olusosun Landfill [OL]).

Table 4. DRASTIC Index computation for Area 1 (Eti-Osa LGA).

\begin{tabular}{ccccc}
\hline Factor & Data & Rating & Weight & Number \\
\hline Depth to water & $0.25 \mathrm{~m}$ & 10 & 5 & 50 \\
Net recharge & $1838 \mathrm{~mm} / \mathrm{yr}$ & 9 & 4 & 36 \\
Aquifer media & Sand & 8 & 3 & 24 \\
Soil media & Sand & 9 & 10 & 1 \\
Topography & $1 \%-2 \%$ & 8 & 5 & 10 \\
Impact of vadose zone & Sand & 10 & 3 & 30 \\
Hydraulic conductivity & $5550 \mathrm{~m} / \mathrm{yr}$ & & 30 \\
\hline
\end{tabular}

Drastic index 208.

Table 5. DRASTIC Index computation for Area 2 (Apapa LGA).

\begin{tabular}{ccccc}
\hline Factor & Data & Rating & Weight & Number \\
\hline Depth to water & $1.78 \mathrm{~m}$ & 9 & 5 & 45 \\
Net recharge & $1838 \mathrm{~mm} / \mathrm{yr}$ & 9 & 4 & 36 \\
Aquifer media & Sand & 8 & 3 & 24 \\
Soil media & Clay & 1 & 2 & 2 \\
Topography & $2 \%-4 \%$ & 3 & 5 & 9 \\
Impact of vadose zone & Clay & 6 & 3 & 15 \\
Hydraulic conductivity & $40.5 \mathrm{~m} / \mathrm{yr}$ & & & 18 \\
\hline
\end{tabular}

Drastic index 149 .

Table 6. DRASTIC Index computation for Area 3 (Surulere LGA).

\begin{tabular}{|c|c|c|c|c|}
\hline Factor & Data & Rating & Weight & Number \\
\hline Depth to water & $3.50 \mathrm{~m}$ & 9 & 5 & 45 \\
\hline Net recharge & $1838 \mathrm{~mm} / \mathrm{yr}$ & 9 & 4 & 36 \\
\hline Aquifer media & Sand & 8 & 3 & 24 \\
\hline Soil media & Loam & 5 & 2 & 10 \\
\hline Topography & $2 \%-4 \%$ & 9 & 1 & 9 \\
\hline Impact of vadose zone & Sand & 8 & 5 & 40 \\
\hline Hydraulic conductivity & $5550 \mathrm{~m} / \mathrm{yr}$ & 10 & 3 & 30 \\
\hline
\end{tabular}

Drastic index 194. 
Table 7. DRASTIC index computation for Area 4 (Shomolu LGA).

\begin{tabular}{|c|c|c|c|c|}
\hline Factor & Data & Rating & Weight & Number \\
\hline Depth to water & $0.15 \mathrm{~m}$ & 10 & 5 & 50 \\
\hline Net recharge & $1838 \mathrm{~mm} / \mathrm{yr}$ & 9 & 4 & 36 \\
\hline Aquifer media & Sand & 8 & 3 & 24 \\
\hline Soil media & Clay & 7 & 2 & 14 \\
\hline Topography & $2 \%-4 \%$ & 9 & 1 & 9 \\
\hline Impact of vadose zone & Clay & 3 & 5 & 15 \\
\hline Hydraulic conductivity & $40.5 \mathrm{~m} / \mathrm{yr}$ & 8 & 3 & 24 \\
\hline
\end{tabular}

Drastic index 172 .

Table 8. DRASTIC index computation for Area 5 (Kosofe LGA).

\begin{tabular}{|c|c|c|c|c|}
\hline Factor & Data & Rating & Weight & Number \\
\hline Depth to water & $14 \mathrm{~m}$ & 3 & 5 & 15 \\
\hline Net recharge & $1838 \mathrm{~mm} / \mathrm{yr}$ & 9 & 4 & 36 \\
\hline Aquifer media & Sand & 8 & 3 & 24 \\
\hline Soil media & Loam & 5 & 2 & 10 \\
\hline Impact of vadose zone & Sand and Gravel with Silt & 6 & 5 & 30 \\
\hline Hydraulic conductivity & $219 \mathrm{~m} / \mathrm{yr}$ & 10 & 3 & 30 \\
\hline
\end{tabular}

Drastic index 155 .

Table 9. DRASTIC Index computation for Area 6 (Ikeja LGA).

\begin{tabular}{ccccc}
\hline Factor & Data & Rating & Weight & Number \\
\hline Depth to water & $2.00 \mathrm{~m}$ & 9 & 5 & 45 \\
Net recharge & $1838 \mathrm{~mm} / \mathrm{yr}$ & 9 & 4 & 36 \\
Aquifer media & Sand & 8 & 3 & 24 \\
Soil media & Clay & 1 & 10 & 1 \\
Topography & $1 \%-2 \%$ & 3 & 5 & 15 \\
Impact of vadose zone & Clay & 6 & 3 & 18 \\
Hydraulic conductivity & $40.5 \mathrm{~m} / \mathrm{yr}$ & & & \\
\hline
\end{tabular}

Drastic index 150.

Table 10. DRASTIC index computation for Area 7 (Alimosho LGA).

\begin{tabular}{ccccc}
\hline Factor & Data & Rating & Weight & Number \\
\hline Depth to water & $15.0 \mathrm{~m}$ & 5 & 5 & 25 \\
Net recharge & $1838 \mathrm{~mm} / \mathrm{yr}$ & 9 & 4 & 36 \\
Aquifer media & Sand & 8 & 3 & 24 \\
Soil media & Clay & 1 & 2 & 02 \\
Topography & $1 \%-2 \%$ & 10 & 1 & 10 \\
Impact of vadose zone & Clay & 3 & 5 & 15 \\
Hydraulic conductivity & $40.5 \mathrm{~m} / \mathrm{yr}$ & 6 & 3 & 18 \\
\hline
\end{tabular}

Drastic index 130. 


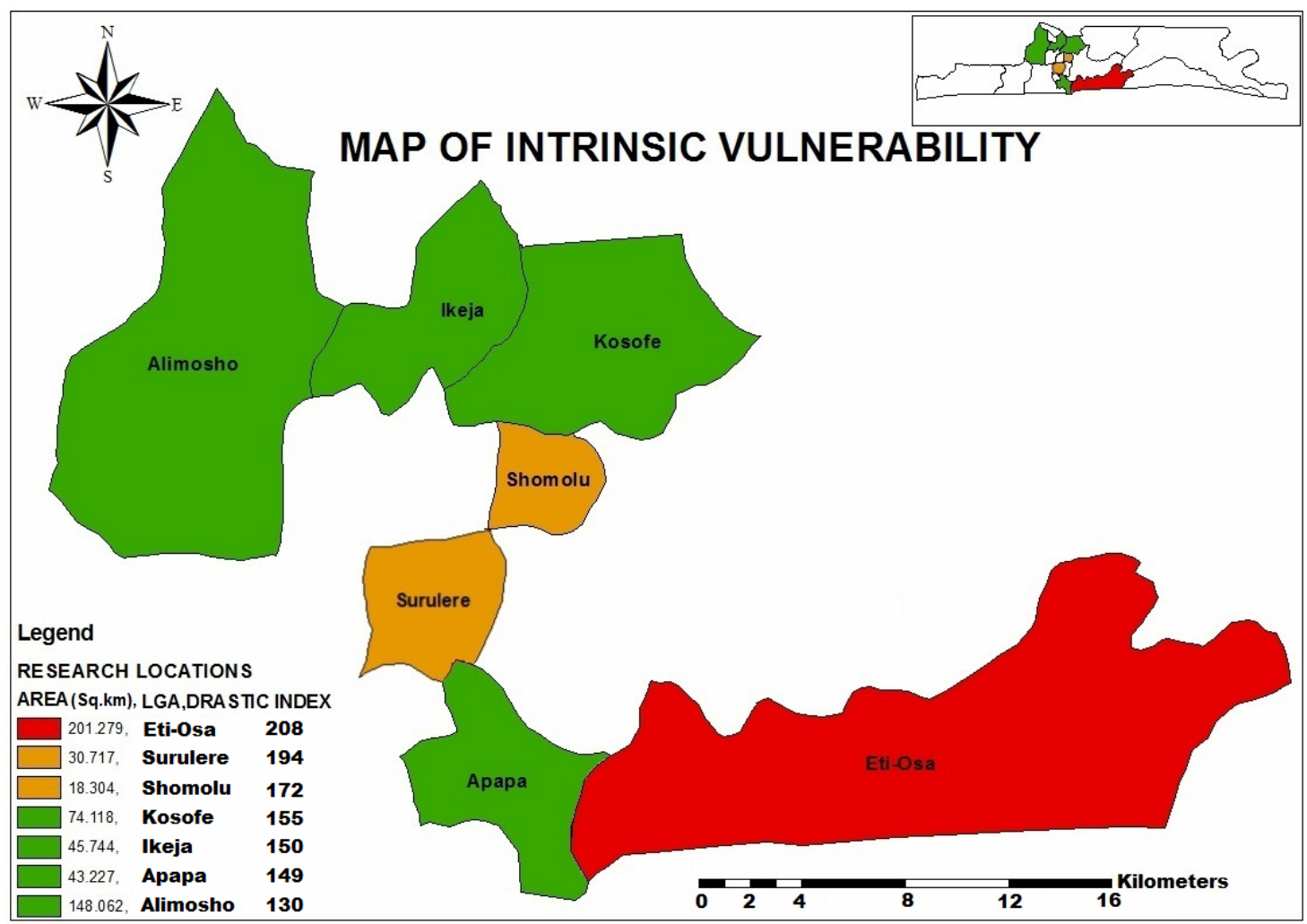

Figure 4. Map of intrinsic vulnerability.

consisting of Ipaja and Gowon Estate suburbs, north west of the study area has the lowest vulnerability index (130), hence the lowest contamination potential.

Classification of DRASTIC index ( $>200$ Very High [Red]; 160 - 200 High [Orange]; 101 - 159 Moderate [Green]).

The resulting DRASTIC values in this application lay between 130 and 208. Since the minimum possible DRASTIC index for using these parameters is 23 and the maximum is 230 , this range was divided into three classes. Thus, the range was classified as; Very High groundwater pollution potential $(>200)$; High groundwater pollution potential (160 - 199) and Moderate groundwater pollution potential (101 - 159). The output map shows that the southeast of the aquifer is under very high vulnerability while central parts of aquifer have high vulnerability, other parts (north, northwest and south) of the study area have moderate vulnerability to pollution. General trends in the results of Generic DRASTIC model depict areas lying between the "moderately high" to "very high" vulnerability categories (Figure 4).

\subsection{Geochemical Analyses Results}

The result of groundwater quality data compiled from literature (Gbadebo, 2008; Adebo and Adetoyinbo, 2009) is presented in Table 2. Area 1 (Eti-Osa LGA) has the highest value of electrical conductivity [EC] $(817 \mu \mathrm{S} / \mathrm{cm})$ and highest chloride $\left(\mathrm{Cl}^{-}\right)$concentration $(393.10 \mathrm{mg} / \mathrm{l})$. This is in tandem with the highest DRASTIC vulnerability index obtained for this zone and its proximity to the Atlantic Ocean with its nudging salt water intrusion. Area 3 (Surulere LGA) has the highest value of Total Dissolved Solids [TDS] (473.10 mg/l). Area 5 (Kosofe LGA) has the highest value of nitrate $\left(\mathrm{NO}_{3}^{-}\right)$concentration $(10.4 \mathrm{mg} / \mathrm{l})$. Area 7 (Alimosho LGA) with the least DRASTIC index, has lower values of electrical conductivity, Total Dissolved Solids [TDS], chloride $\left(\mathrm{Cl}^{-}\right)$concentration and nitrate $\left(\mathrm{NO}_{3}^{-}\right)$than Area 1 (Eti-Osa LGA) and Area 2 (Apapa LGA) with higher DRASTIC vulnerability indices but not the least values as would have been ordinary expected.The chemical analysis results show that both the southeast and northwest west parts of study area aquifer (very high and moderate vulnerability zones) have higher nitrate concentration relative to the rest of aquifer, that are located in high vulnerability zone. The total dissolved solids concentration is high in the south and south-eastern parts as expected.

\subsection{Statistical Correlation and Validation of DRASTIC Model Results}

The results from the statistical comparison between 
groundwater vulnerability map (Figure 4), the data layers, the groundwater quality data (Table 2) and the distances from groundwater pollution aggravating land cover features for Lagos metropolis (Table 3 ) are presented in Table 11. The values for the net recharge (R) and aquifer media (A) were the same for the seven zones within the study area, hence there was no trend to give a comparison in Pearson correlation matrix.

The results from the Pearson's correlation analysis indicate considerably high correlations $(r=0.85, r=0.82$, $r=0.78$ ) between Intrinsic DRASTIC vulnerability index (VI) and the layers, soil media, impact of vadose zone and hydraulic conductivity respectively. These parameters have a dominant effect on the resulting intrinsic drastic vulnerability index. The Pearson's $r$ correlation analysis between the seven DRASTIC input parameters generally indicates low to high correlations (Table 11). Strong correlations exists between the parameters such as impact of vadose zone and hydraulic conductivity $(r=$ $0.90)$, soil media and hydraulic conductivity $(r=0.82)$, soil media and impact of vadose zone $(r=0.67)$. The very strong relationship between the impact of vadose zone, soil media and hydraulic conductivity layers can be ascribed to the fact that these parameters were derived from soil subsurface exploration borehole logs within the study area. This result points out the fact that the model results would be improved if more water supply borehole logs were available. Topography parameters utilized in this study show negative correlations with depth to water and soil media ( $r$ values -0.51 and -0.06 ), low positive correlations with impact of vadose zone and hydraulic conductivity ( $r$ values 0.07 and 0.00 ). This implies minimal contribution of the topography parameter to the DRASTIC vulnerability index for this site. From the results presented in Table 11, $\mathrm{Cl}^{-}$and $\mathrm{NO}_{3}$ concentrations in the study area are inversely related $(r=-0.08)$. This possibly suggests that different processes are responsible for the occurrence of the high concentrations of these pollutants in the groundwater (i.e., nitrate pollution from anthropogenic sources vs. saltwater intrusion). Chloride concentrations in the study area present weak to moderately high positive correlations with DRASTIC input layers and models, where $r$ values range from 0.07 to 0.57 . This is probably because the highest groundwater $\mathrm{Cl}^{-}$concentrations occur in areas close to coastal zone (up to $393.1 \mathrm{mg} \cdot \mathrm{L}^{-1}$ ), where DRASTIC vulnerabilities are also high $(\mathrm{VI}=172-208)($ Figure 4).

\section{Conclusion}

This study demonstrated the combined use of the DRASTIC model and Geographic Information System

Table 11. Pearson correlation matrix between DRASTIC data layers, Intrinsic DRASTIC vulnerability index (VI), Total dissolved solids (TDS), Chloride $\left(\mathrm{Cl}^{-}\right)$and Nitrate $\left(\mathrm{NO}_{3}^{-}\right.$) concentrations (in $\mathbf{m g} \cdot \mathbf{L}^{-1}$ ), Distance from Atlantic Ocean (DAO), Distance from Lagos Lagoon (DLL), and Distance from Olusosun Landfill (DOL) [in km] in groundwater in Lagos, Nigeria.

\begin{tabular}{|c|c|c|c|c|c|c|c|c|c|c|c|c|c|}
\hline Layer & D & $\mathbf{R}$ & $\mathbf{A}$ & $\mathbf{S}$ & $\mathbf{T}$ & I & C & VI & TDS & $\mathrm{Cl}^{-}$ & $\mathrm{NO}_{3}^{-}$ & DAO & DLL \\
\hline \multicolumn{14}{|l|}{$\mathbf{R}$} \\
\hline \multicolumn{14}{|l|}{ A } \\
\hline $\mathbf{S}$ & 0.29 & & & & & & & & & & & & \\
\hline $\mathbf{T}$ & -0.51 & & & -0.06 & & & & & & & & & \\
\hline I & 0.05 & & & 0.67 & 0.07 & & & & & & & & \\
\hline C & -0.06 & & & 0.82 & 0.00 & 0.90 & & & & & & & \\
\hline VI & 0.56 & & & 0.85 & -0.21 & 0.82 & 0.78 & & & & & & \\
\hline TDS & 0.40 & & & 0.06 & -0.10 & 0.62 & 0.23 & 0.53 & & & & & \\
\hline $\mathrm{Cl}^{-}$ & 0.57 & & & 0.17 & 0.12 & 0.38 & 0.07 & 0.51 & 0.75 & & & & \\
\hline $\mathrm{NO}_{3}^{-}$ & -0.63 & & & 0.33 & 0.50 & 0.35 & 0.52 & 0.04 & -0.28 & -0.08 & & & \\
\hline DAO & -0.54 & & & -0.41 & 0.49 & -0.47 & -0.33 & -0.63 & -0.62 & -0.65 & 0.04 & & \\
\hline DLL & -0.63 & & & -0.58 & 0.71 & -0.36 & -0.38 & -0.68 & -0.35 & -0.35 & 0.15 & 0.89 & \\
\hline DOL & 0.62 & & & 0.44 & -0.51 & 0.42 & 0.27 & 0.65 & 0.61 & 0.62 & -0.18 & -0.98 & -0.92 \\
\hline
\end{tabular}

[D] Depth to water table, [R] Recharge (Net), [A] Aquifer Media, [S] Soil Media, [T] Topography (Slope), [I] Impact of Vadose Zone, [C] Conductivity (Hydraulic), [VI] Vulnerability Index, [TDS] Total Dissolved Solids, $\left[\mathbf{C l}^{-}\right]$Chloride, [ $\left.\mathbf{N O}_{3}^{-}\right]$Nitrate, [DAO] Distance from Atlantic Ocean, [DLL] Distance from Lagos Lagoon, [DOL] Distance from Olusosun Landfill. 
(GIS) as an effective method for groundwater pollution vulnerability assessment. The result shows that Eti-Osa LGA has a very high vulnerability index 208 , and therefore has the greatest pollution potential while Surulere LGA and Shomolu LGA have high vulnerability indices of 194 and 172 respectively. Kosofe LGA, Alimosho LGA, Apapa LGA and Ikeja LGA have moderate vulnerability indices of 155, 130, 149 and 150 respectively. The high indices obtained for inland Surulere LGA and Shomolu LGA with approximate distances of about 8.0 $\mathrm{km}$ and $14.0 \mathrm{~km}$ respectively from the Atlantic Ocean could be due to other factors such as distance to the Lagos lagoon, distance to the Olusosun landfill, urban development/environmental change and changes in the hydrological fluxes in the urban watershed. The study suggests that the DRASTIC model validated with groundwater quality data and the estimation of pollution aggravating land cover feature proximity can be used for prioritization of vulnerable areas in order to prevent the further pollution to already polluted areas. This approach could be used to develop a system to identify areas where attention or protection effort is required. There should be a detailed and frequent monitoring in the high and very high vulnerable zones in order to monitor the changing level of pollutants. The result obtained would be improved if more water supply borehole logs were available.

\section{REFERENCES}

[1] J. W. A. Foppen and J. F. Schijven, "Evaluation of Data from the Literature on the Transport and Survival of Escherichia coli and Thermotolerant Coliforms in Aquifers under Saturated Conditions," Water Resources, Vol., 40, No. 3, 2006, pp. 401-426.

[2] World Health Organization (WHO), "Global Water Supply and Sanitation Assessment 2000 Report,” 2013. http://www.who.int/water_sanitation_health/monitoring/g lobalassess/en/

[3] R. C. M. Nobre, O. C. Rotunno Filho, W. J. Mansur, M. M. M. Nobre and C. A. N. Cosenza, "Groundwater Vulnerability and Risk Mapping Using GIS, Modeling and a Fuzzy Logic Tool," Journal of Contaminant Hydrology, Vol., 94, No. 3, 2007, pp. 277-292.

doi:10.1016/j.jconhyd.2007.07.008

[4] L. Aller, T. Bennett, J. H. Lehr, R. Petty and G. Hackett, "DRASTIC: A Standardized System for Evaluating Ground Water Potential Using Hydrogeologic Settings," United States Environmental Protection Agengy (USEPA), Ada, 1987.

[5] S. S. D. Foster, "Fundamental Concepts in Aquifer Vulnerability, Pollution Risk and Protection Strategy," Proceedings and Informations/TNO Committee on Hydrological Research, Vol. 38, 1987, pp. 36-86.
[6] D. Van Stempvoort, L. Ewert and L. Wassenaar, "AVI: A Method for Groundwater Protection Mapping in the Prairie Provinces of Canada," PPWD Groundwater and Contaminants Project, National Hydrology Research Institute, Saskatoon, 1992.

[7] R. C. Palmer and M. A. Lewis, "Assessment of Groundwater Vulnerability in England and Wales," In: N. S. Robins, Ed., Groundwater Pollution, Aquifer Recharge and Vulnerability, Geological Society Special Publication, Vol. 130, 1998, pp. 191-198.

[8] I. S. Babiker, M. A. A. Mohamed, T. Hiyama and K. Kato, "A GISbased DRASTIC Model for Assessing Aquifer Vulnerability in Kakamigahara Heights, Gifu Prefecture, Central Japan," Science of the Total Environment, Vol. 345, No. 1-3, 2005, pp. 127-140.

doi:10.1016/j.scitotenv.2004.11.005

[9] N. S. Robins, P. J. Chilton and J. E. Cobbing, "Adapting Existing Experience with Aquifer Vulnerability and Groundwater Protection for Africa," Journal of African Earth Sciences, Vol. 47, No. 1, 2007, pp. 30-38.

doi:10.1016/j.jafrearsci.2006.10.003

[10] M. G. Rupert, "Calibration of the DRASTIC Ground Water Vulnerability Mapping Method," Ground Water, Vol. 39, No. 4, 2001, pp. 630-635. doi:10.1111/j.1745-6584.2001.tb02350.x

[11] I. R. Lake, A. A. Lovett, K. M. Hiscock, M. Betson, A. Foley, G. Sünnenberg, S. Evers and S. Fletcher, "Evaluating Factors Influencing Groundwater Vulnerability to Nitrate Pollution: Developing the Potential of GIS," Journal of Environmental Management, Vol. 68, No. 3, 2003, pp. 315-328. doi:10.1016/S0301-4797(03)00095-1

[12] T. C. Pizani, G. C. Silva Júnior and C. Bettini, "Vulnerability Assessment to Aquifer Contamination in Resende Sedimentary Basin, Brasil, with the DRASTIC Method," International Society for Soil Mechanics \& Geotechnical Engineering (ISSMGE) 4th International Congress on Environmental Geotechnical Engineering (ICEG), Rio de Janeiro, 12-16 August 2002, pp. 11-15.

[13] D. Thirumalaivasan, M. Karmegam, K. Venugopal, "AHPDRASTIC: Software for Specific Aquifer Vulnerability Assessment Using DRASTIC Model and GIS," Environmental Modelling and Software, Vol. 18, No. 7, 2003, pp. 645- 656. doi:10.1016/S1364-8152(03)00051-3

[14] M. Chitsazan and Y. Akhtari, "A GIS-Based DRASTIC Model for Assessing Aquifer Vulnerability in Kherran Plain, Khuzestan, Iran," Water Resources Management, Vol. 23, No. 6, 2009, pp. 1137-1155. doi:10.1007/s11269-008-9319-8

[15] H. Baalousha, "Assessment of a Groundwater Quality Monitoring Network Using Vulnerability Mapping and Geostatistics: A Case Study from Heretaunga Plains, New Zealand," Agricultural Water Management, Vol. 97, No. 2, 2010, pp. 240-246. doi:10.1016/j.agwat.2009.09.013

[16] N. G. Tait, D. N. Lerner, J. W. N. Smith and S. A. Leharne, "Priorisation of Abstraction Boreholes at Risk from Chlorinated Solvent Contamination on the UK Permo-Triassic Sandstone Aquifer Using a GIS," Science of the Total Environment, Vol. 319, No. 1, 2004, pp. 77-98. 


\section{doi:10.1016/S0048-9697(03)00438-8}

[17] H. Huan, J. S. Wang and Y. Teng, "Assessment and Validation of Groundwater Vulnerability to Nitrate Based on a Modified DRASTIC Model: A Case Study in Jilin City of northeast China," Science of the Total Environment, Vol. 440, 2012, pp. 14-23. doi:10.1016/j.scitotenv.2012.08.037

[18] C. Güler, M. A. Kurt, M. Alpaslan and C. Akbulut, "Assessment of the Impact of Anthropogenic Activities on the Groundwater Hydrology and Chemistry in Tarsus coastal Plain (Mersin, SE Turkey) Using fuzzy Clustering, Multivariate Statistics and GIS Techniques," Journal of Hydrology, Vol. 414-415, 2012, pp. 435-451.

[19] UN-HABITAT, "The State of African Cities 2008: A Framework for Addressing Urban Challenges in Africa," United Nations Human Settlements Programme, Nairobi, 2008.

[20] K. Awosika, T. Akosa, B. Akanji, B. Daramola and G. Akpokodje, "State Report Lagos State," In: N. Rao and R. Palmer-Jones, Eds., Gender and Growth AssessmentNigeria, Department for International Development (DFID) and Canadian International Development Agency (CIDA) Report, Lagos, 2009, pp. 1-37.

[21] P. Okunola, "Lagos under Stress," Dossier Habitat Country Reports, Fiji, 1996.

[22] I. O. Adelekan, "Vulnerability of Poor Urban Coastal Communities to Climate Change in Lagos, Nigeria," 5th Urban Research Symposium, Marselles, 2009, pp. 1-18. http://siteresources.worldbank.org/INTURBANDEVELO PMENT/Resources/336387-1256566800920/6505269-1 268260567624/Adelekan.pdf

[23] Federal Department of Agricultural Land Resources (FDALR), "Reconnaissance Soil Survey of Nigeria," FDALR,
Lagos, 1995, p. 281.

[24] BBC, "Weather BBC Weather Lagos Nigeria," BBC, London, 2011.

[25] ESRI, “ArcGIS Version 9.3. 380," New York Street, Redlands, 2009.

[26] J. Vrba and M. Civita, "Assessment of Gronudwater Vulnerability," In: A. Zaporozec and J. Vrba, Eds., Guidebook on Mapping Groundwater Vulnerability, International Contributions to Hydrogeology, International Association of Hydrogeologists, Lingen, 1994, pp. 31-38.

[27] O. O. Ojuri, S. A. Ola, D. L. Rudolph and J. F. Barker, "Contamination Potential of Tar Sand Exploitation in the Western Niger-Delta of Nigeria: Baseline Studies," Bulletin of Engineering Geology and the Environment, Vol. 69, No. 1, 2010, pp. 119-128. doi:10.1007/s10064-009-0239-5

[28] A. M. Gbadebo, "Assessment of Quality of Groundwater from Lagos Metropolis and Its Possible Health Implications," In: J. Freid and J. Scherfig, Eds., Proceedings International Conference on Water Scarcity, Global Changes, and Groundwater Management Responses, The University of California, Irvine, 2008, pp. 905-910.

[29] B. A. Adebo and A. A. Adetoyinbo, "Assessment of Groundwater quality in Unconsolidated Sedimentary Coastal Aquifer in Lagos State, Nigeria," Scientific Research and Essay, Vol. 4, No. 4, 2009, pp. 314-319.

[30] E. O. Longe and L. O. Enekwechi, "Investigation on Potential Groundwater Impacts and Influence of Local Hydrogeology on Natural Attenuation of Leachate at a Municipal Landfill," International Journal of Environmental Science and Technology, Vol. 4, No. 1, pp. 133-140. 